\title{
The Effect of Multicultural Music Education on Folk Music Culture Delivery
}

\author{
Zhengchang Zhou ${ }^{1, \text { a }}$ \\ ${ }^{1}$ Music and Dance Institute of Qujing Normal College \\ hunter2011@foxmail.com
}

Keywords: Multicultural, Music Culture, Music Education, Delivery

\begin{abstract}
The exiting form of music culture determines that music education is certain representing form of human music culture. Music education as certain music culture form counteracts on certain music culture noumenon to make music education show itself profound culture significance and spirit intension. Only more attention to humanity intension of music education, music education research on great background of music culture has vitality. Multicultural music educationps action is to fully exert culture delivery function of music education, to make music education become music culture form having profound folk details on music culture delivery activity.
\end{abstract}

\section{Introduction}

Musical ideas and musical events musical culture as a behavior shared by certain human groups, must be acquired by an organized, purposeful behavior can be learned music education. Music education is a musical and cultural formation, development of the necessary conditions. Based on the concept of music education in different cultural understanding of all kinds of music, choice of teaching content and teaching methods of use, etc., is bound to reflect the traditional folk music of different cultures, interests, values, and thereby forming a national characteristics of music education . Thus, multicultural music education plays an important role in the cultural heritage of ethnic music [1].

\section{The Music Culture and Multicultural Music Education}

Music and music education has a deep-rooted cultural ties, therefore, music education is bound to become music culture in the form of musical activity has a profound cultural heritage of ethnic heritage. Although the relationship between music culture and music education is due to the layers of phase, interest income linked, but not equivalent to the musical culture of music education.

The connotations of music culture and music education. Music culture is the expression of cultural forms of human thought with musical language, so inevitable but with distinctive national features affected the nation's traditional culture. Cultural characteristics of any nation in the world has to give the desired attention and heritage, based on different cultural backgrounds and music education for all types of music, different understanding, reflecting the traditional characteristics of different ethnic music culture, interest features, while showing a music differences in cultural values, and thus the formation of the national characteristics of music education [2].

In music education as part of the musical culture at the same time, we will be the relationship between music education and music culture to study the place of spiritual music. But it must be emphasized that the musical culture of music education and music theory and are attached to the system level and spiritual music culture. Even the family of music education, music education community is not haphazard, as long as the system, scientific music education, all of which contain "institutionalized" color. For music is part of music culture theory spiritual level, it should make findings to spread through music education, offer new value, and create music theory Institute benefits generated for the entire field of music culture, music and the whole academic community ideas, new concepts, will become a valuable wealth of human culture. Thus, the music culture of 
music education activities must be diverse, three-dimensional, mutual penetration, it is for the inheritance and development of music culture of the tremendous potential can not be ignored.

Diversification heritage features of Music Education. Musical and cultural traditions are reflected in the general characteristics of the national spirit, ideology, a national music culture, norms and ways of thinking and so on. Four aspects of value systems, knowledge and experience, ways of thinking, music symbols together constitute the basic content of the music and cultural traditions. The formation of these moments in music education is throughout the whole process, constraints and impact of education ideas, innovation and teaching methods of updating the content of education.

First, the music directly from the language of the voice pitch, which determines the representative of national culture of music in constant pursuit of pitch, timbre, sound intensity, sound length novel, and must be unified in a style to reflect the same ethnic music culture perfection and unity, this unity thinking what style of music that is the music of different ethnic values constraints. Secondly, as a musical language support - music notation musical and cultural traditions of one of the basic content, it not only reflects the distinctive music education values, and thus directly affect the formation of ideas and teaching methods of education, so the music culture The impact is very profound.

Music is a world phenomenon, multicultural music education to guide students to think critically about the world of music and different music to help students develop a global perspective. However, it must be emphasized that multicultural music education should first focus will be mainly on the presentation of the national cultural identity, on this basis will it be possible to make educated nation has a unique culture, and then the differences and understand a variety of music cultural and social characteristics of music and musical styles. Cultural phenomenon of global vision is the development trend of modern music education, music education faces music values and outlook turning point, should first cultivate love national music culture of the nation, and thus understand other people's music culture. School music education can play a role in the cultural heritage of folk music, the ability to treat different values of equality of national culture, a new coordinate people look at multicultural music education values and measure its effects [3].

\section{The Multicultural Music Education and Folk Music Culture Delivery}

Multicultural music education is the main channel of folk music culture delivery and development. Music culture is also present in the social life. In working life and folk activities, working people entertain themselves through music, so music education unconscious behavior (such as: environmental influence, folk activities, social musical and cultural activities, etc.) is the traditional musical culture from generation to generation of one through. However, conscious, purposeful activity to teach music education is the most important musical and cultural tradition, experience, skills, it can make educated in a short time to maximize access to knowledge of the system, therefore and it is a national multicultural music education the main channel music cultural heritage and development.

However, the preservation and maintenance of music education musical culture is by selecting, sorting and delivery of musical culture to achieve. In general, music education musical culture selection and finishing are based on the level of mental development and social needs and age characteristics educated these two important factors. Music cultural content in line with the needs of society and educated psychological status as an integral part of the music education system; not meet the elements of the musical culture of social development, not in compliance with the educated mental condition to give his exclusion, weakening. Thus, the choice of music education and organize music culture elements, namely music education teachings, is also a treasure house of human music culture is the most important, most central part, to a certain extent, it reflects the style of a national music culture features and spiritual connotation, is the human essence of music in cultural treasures.

The multicultural music education draws and spreads the exotic musical culture so as to promote the development of the national music culture. Human musical culture in the process of passing, left, accumulation, create, update, new music and cultural factors attendant. Therefore, music and cultural changes become an indisputable fact. It has a pivotal role in the dissemination of 
music culture changes, which make the music culture flows between society and society, from region to region. Music culture propagation need to have some means of transmission, propagation method media, music education, then there is a unique advantage in these areas:

1 , music education has function on the spread of content selection, sorting, so that the core of the music culture to spread;

2, receiving feedback information in music education process, correcting communication channels and content, to ensure the spread of musical culture of authentic nature

3 , using all possible means of education, to maximize the range of spread;

4. Use the "optimal" teaching methods, so that those who pass easily accepted, so that those who pass and those who pass to establish a good, stable relations.

Innovation is another important dimension of music cultural heritage and change. The process of music education in a sense can be considered as the process of creating music culture. Instructor and instructed by various physical and mental condition and own values of the differences, making the process of music education is not simply replicate previous musical culture, but the integration, aggregation local music culture and foreign musical culture, derived from new musical cultural elements, giving new meaning to music culture, and for the development of the culture of music culture innovative talents [4].

Changes in the tradition and music culture in the process, learn music education can promote integration of the various musical cultures, but also stand still hinder inter-cultural exchange of music; either because of training creative talents to enhance the vitality of the music culture changes, but also because educated blind pursuit of innovation and the loss of the national music culture, resulting in the depletion of the creative source of the music culture; either because foreign musical culture pooled spirit, norms, technology, and thus contributing to the development of the national music culture, but also because educated foreign spirit worship music culture, norms, technology and contempt local music culture, resulting in the development of national music culture of "lag"; both the diffusion of new music and cultural factors, communication, making it for all citizens' public Music education ", or it can be limited to a few people, a few people-oriented" music elite education. "Music education is so has both a positive and negative characteristics to music education we provide a focus theory. If you ignore music education may produce changes in musical culture, heritage of the negative effects, and exaggerated its positive effect, it will make music education deviate from the correct direction, hinder the development of musical heritage and culture. Multicultural music education should be effectively and reasonably learn foreign musical culture propagation, can really play their heritage and promote the development of national music culture role [5].

Multicultural music education has features of enhancing musical cultural cohesion. Regardless of culture in a way are integrated into one. Because the socio-political and economic development, the need to adapt to their culture. To rely on education and social development, as an important part of the musical culture of music education only integrate into society, in the overall development of science and technology, economy and society can be developed to achieve to make music culture around the social, political, economic, and coordinated with form and with the Chinese national cohesion and rich cultural connotation of the music. People in the music education activities to establish the correct values of music, get good feelings influence, so shared a musical culture, and derive identity. Because of different categories of national languages in the world, resulting in differences in tone of the language, thus forming a musical basic material for the musical expression of different nationalities, the basic means basic techniques are not the same (eg: scales, melody, tuning, rotary method ), resulting in a diversity of musical styles of all ethnic groups. All nations of the world have marked their own musical culture ethnic attributes, and musical style has become a standard piece of music to identify national ownership. Thus, in modern music education, the ancient form of teaching mouth and heart, as well as the influence of folk culture environment for multicultural music education, still it has important significance and worth exploring. Because of multicultural music education is still an important part of modern music education essential, we thereby recognize the cultural integrity of leaving music, music education can not understand. 


\section{Conclusion}

The multicultural music education makes the heritage and development of national musical culture to of through purposed music cultural and educational activities. The multicultural music enhances the cohesion of folk music culture education and promotes the pace of innovation of national music culture. Only based on the local folk music culture, continue to learn and learn the essence of foreign national music culture, multicultural music education can realize the educational value of national music culture, and promote the inheritance and development of national music culture.

\section{References}

[1] X.Zhang, The heritage and development of folk music in the background of multicultural music education, J. Arts Education, 5(2007) 46-47.

[2] C.Li, The heritage and development of folk music in the background of multicultural music education, J. Music Grand. 11(2006) 26-30.

[3] C.Y.Wang, Universities musical education and the national music culture inheritance, J. Shanghai Financial. 12(2009) 56-58.

[4] J.X.Li, The heritage and development of national music in the background our world multicultural music education, J. Art and Science .9(2009) 19-22.

[5] Y.X.Zhang, The music education under the shadow of colonialism, J. Chinese Music. 4(2007) 129-132. 